Available online http://www.lumenpublishing.com/journals/index.php/lumenlaw ISSN: 2284 - 5968 (print), ISSN: 2284 - 5968 (electronic)

Logos Universality Mentality Education Novelty Section: Law

2017, Volume V, Issue 2, December, pp. 48-66

\title{
Citizens' Trust in the Romanian Police
}

\section{Larisa Ionela PAŞNICIUC}

https://doi.org/10.18662/lumenlaw.4

Covered in:

CEEOL, Index Copernicus, Ideas RePeC, EconPapers, SocioNet, HeinOnline 


\title{
Citizens' Trust in the Romanian Police
}

\author{
Larisa Ionela PAȘNICIUC ${ }^{1}$
}

\begin{abstract}
In order for the Romanian Police to be able to perform its tasks, it requires for citizens to trust their work. Because of the different opinions that have arisen over time, an analysis of the trust citizens have in this institution is a welcome one. This paper aims to discover the level of trust citizens have in the Romanian Police. Being an issue that weighs a lot in the public image and the sphere of social life, this research is a topical one and the analysis of the results could lead to better communication and the strengthening of the relationship between the citizens and the Romanian Police. The present paper aims to create an image of the confidence that the citizens of a region of NorthEast Romania have in the Romanian Police. The objective of this research is to measure the citizens' trust in the staff of the Romanian Police, respectively the respect they have and at the same time the elements that could positively or negatively influence this aspect. Based on data analysis, the premise according to which the level of corruption influences the trust in the Police was found to be valid. Most subjects considered this to be one of the main reasons for which people began to lose their trust in the police. This factor is not isolated and is not only encountered within the Romanian Police, and it also does not refer only to this institution. Once corruption occurs at the level of the state, it is inevitable to spread it to the institutions is connected with. This does not prove that such actions actually take place, but citizens associate state and authority with the police, and that's where the suspicions arise. Also, if a policeman is discovered committing the crime of receiving bribery, not only will he suffer, but the whole institution he represents will.
\end{abstract}

Behavior and training of police officers are two factors that have an important role in increasing or decreasing confidence in the Romanian Police. The image of the Romanian Police is influenced by several factors and the citizens must take into account not only the mistakes made by the staff working in this institution, but also the results obtained from the missions they have carried out.

Keywords: Police, public confidence, ethical behavior, public image of the cop.

\footnotetext{
${ }^{1}$ Faculty of Law and Administrative Sciences, Stefan cel Mare University from Suceava, Romania, larisaionela07@yahoo.com.
} 


\section{Introducere}

Într-o țară democrată, cetăţenii trebuie să se simtă în siguranță şi, totodată, să li se asigure respectarea drepturilor pe care aceştia le dobândesc de-a lungul vieții. Pentru a se putea crea această situație, este nevoie de instituțiile publice, rolul acestora fiind de a pune în aplicare normele legale şi de a veghea asupra respectării lor. Un element cheie care leagă aceste două aspecte, cetățenii şi instituțiile publice, este încrederea.

Pentru ca totul să funcționeze aşa cum se cuvine, încredere trebuie să existe atât între cetățeni, cât şi între cetățeni şi autorități. Totodată, încrederea pe care o capătă cetățenii ii face pe aceştia să fie mai activi pe plan social, dar nu numai în viața privată, ci şi în cea publică.

\section{Literatura de specialitate}

Deoarece lumea este într-o continuă schimbare, tot ce se întâmplă în jurul acesteia trebuie să se adapteze la noile situații în cel mai scurt timp.

Atât la nivel naţional, cât şi la nivel internaţional au avut loc numeroase cercetări cu privire la încrederea acordată instituțiilor, oamenilor sau figurilor politice. Nu există o singură definiție a încrederii care ar trebui folosită în toate cazurile, de aceea aceasta evoluează şi se pliază pe fiecare domeniu în parte. De cele mai multe ori, încrederea este privită ca pe un fel de siguranță pe care o are o persoană într-o altă persoană sau, de ce nu, întro instituție. Mai mult, va crede că subiectul în cauză va acționa în favoarea acesteia, în interesul ei, cu toate că ar exista mai multe motive potrivit cărora acest lucru nu s-ar întâmpla.

Având în vedere că România este o țară democratică, este importantă studierea nivelului de încredere pe care cetățenii îl au faţă de instituții, deoarece acest fapt stă la baza societății civile şi la consolidarea acesteia. Unii analişti consideră că această încredere ar fi la acelaşi nivel cu încrederea în semeni din punct de vedere al importanței acestora în ceea ce priveşte dezvoltarea socială a unei națiuni.

Încrederea a făcut obiectul multor studii în ultimii ani, chiar INSCOP Research a efectuat o cercetare în aprilie $2016 \mathrm{cu}$ privire la încrederea în instituții. Ancheta a avut în vizor mai multe categorii de instituții din România, precum cele interne (politice, executive, sociale şi private) şi cele externe (instituțiile internaționale). Metoda folosită a fost un chestionar aplicat pe un eşantion format din 1063 persoane, acestea făcând parte atât din mediul rural, cât şi din mediul urban. Perioada în care a fost realizat acest sondaj este 21-28 martie 2016. 
În urma analizării datelor a reieşit faptul că Armata, făcând parte din instituțiile executive, se bucură de o încredere de $76,3 \%$, mai mare, cu aproximativ un procent față de $75,4 \%$, rezultat al unui sondaj realizat în perioada noiembrie 2015 (INSCOP Research, 2015b).

Un element semnificativ care a influențat încrederea pe care o au cetățenii în instituțiile interne a fost nefericitul eveniment de la Colectiv. În urma acestuia, încrederea a crescut cu două procente față de nivelul pe care îl avea înaintea producerii acestui eveniment. În luna septembrie, în urma unui sondaj efectuat de către INSCOP, Armata avea un nivel de încredere de $73,8 \%$, iar în decembrie, după evenimentul de la Colectiv, procentul a crescut până la 75,4\% (INSCOP Research, 2015a).

În urma analizării rezultatelor, un eveniment important la nivel național poate modifica încrederea pe care o acordă cetățenii instituțiilor chiar şi cu câteva procente. Aşadar, reiese că spațiul public afectează viața privată a cetățenilor şi părerile acestora, dar este valabilă şi varianta inversă.

\section{Imaginea politistului în societate}

Polițistul este unul dintre principalele modele ale societății, deoarece acționează în interesul cetățenilor cu scopul apărării acestora. Această profesie nu este ca oricare alta, dar este una complexă care implică mai multe arii, printre care şi societatea. A fi polițist presupune un contact permanent cu cetățenii şi o reputație impecabilă având în vedere că este organul statului şi reprezintă legea şi ordinea.

Pentru a avea succes în această profesie, poliţistul trebuie să fie indulgent cu cei din jurul său, să nu provoace altercații, să-şi susţină părerile cu argumente bine structurate şi să asculte ce au ceilalți de spus fără a-i judeca (Ştefan, 2013, p. 330).

Rolul poliției este unul esențial în orice comunitate, iar eficacitatea acesteia provine din acceptarea acțiunilor efectuate de către polițişti şi din sprijinul acordat de cetățeni. Pentru a se ajunge la relaţii de cooperare între societate şi polițişti este nevoie de un grad ridicat de încredere şi confidențialitate, care nu este tocmai uşor de realizat.

Comportamentul pe care îl are polițistul în cadrul comunității crește respectul atât pentru organele de poliție, cât şi pentru instituție în sine. În ceea ce priveşte relațiile informale cu publicul, polițistul are o datorie civică şi morală să ajute la crearea unui cadru benefic acestora şi să ajute la dezvoltarea lor, chiar şi în acele situații în care pare imposibil realizarea acestui lucru. Cei şapte ani de acasă nu trebuie să lipsească din experienţa polițistului, acest aspect împreună cu cunoştințele şi abilitățile dobândite în 
timpul formării profesionale îl ajută pentru a desfăşura activităţile în cel mai bun mod posibil.

In ceea ce priveşte comportamentul polițistului, societatea este foarte atentă şi critică dur orice abatere, oricât de mică ar fi. Acţiunile acestuia sunt analizate şi vor avea o importanţă ridicată atunci când cetățeanul încearcă să îşi facă o imagine despre acesta sau despre instituția pe care o reprezintă. De exemplu, dacă un polițist îşi petrece o mare parte din timp prin baruri consumând băuturi alcoolice, cei din jurul său nu vor avea o părere tocmai pozitivă despre acesta, astfel integritatea şi profesionalismul fiind nişte calități care vor avea de suferit. Atunci când un polițist de sex feminin este surprins în ipostaze nu tocmai decente, iar acestea sunt fotografiate, imaginea acestuia va fi denigrată, competența sa fiind pusă în discuție.

De cele mai multe ori, un polițist este privit de către societate ca fiind acel model demn de urmat. Acest fapt este cel mai întâlnit, deoarece se presupune că acesta respectă dispozițiile legale, acționează în litera şi spiritul legii, acționează în interesul societății, astfel fiind văzut ca făcând întotdeauna ceea ce este bun, ce este potrivit normelor civice.

Polițistul reprezintă acea persoană în care cetățenii pot avea oricând încredere şi care nu va face absolut nimic pentru a leza drepturile altei persoane. Este respectat de către societate atât pentru faptele sale, dar şi pentru riscul pe care şi-l asumă pentru a putea asigura liniştea şi ordinea publică.

Membrii comunităţii de obicei îşi formează o opinie de îndată ce interacționează cu un polițist. Dar, desigur, şi părerile celorlalte persoane, care au avut un contact direct sau nu cu polițiştii, vor influența felul în care se percep lucrurile. Pentru a câştiga încrederea publicului, nu întotdeauna totul merge aşa cum este plănuit, mai apar dezamăgiri, iar nivelul stresului nu este unul scăzut. Aceste aspecte țin de viaţa reală a unui polițist. Acesta când şi-a terminat orele de muncă, nu înseamnă că nu va mai fi în slujba cetățenilor, iar dacă va exista o situație care necesită implicarea acestuia, ezitarea nu-şi va avea locul.

În zilele acestea, există din ce în ce mai mulți polițişti care au studii superioare (au absolvit facultatea de drept) şi discută cu procurorii, judecătorii sau avocații ca de la egal la egal, având cunoştinţe juridice şi fiind în cunoştinţă de cauză (Ştefan, 2013, p. 332). De asemenea, numărul celor care sunt de temut creşte, deoarece ei nu vor încălca niciodată legea şi îi vor găsi pe cei care o fac cu orice preţ, iar aceştia din urmă vor avea de plătit pentru ceea ce fac. Nu trebuie trecuți cu vederea polițiștii care se ocupă şi de 
partea de cercetare, care urmează studii doctorale sau publică diferite opere de specialitate. $\mathrm{Cu}$ toate acestea, societatea va înţelege că şi generaţia profesioniştilor şi intelectualilor din poliție creşte pe zi ce trece.

Odată cu această funcție, cetățenii deja au alte aşteptări de la persoana numită. Polițistul trebuie să se comporte în aşa fel încât să nu aducă atingeri reputației instituției pe care o reprezintă şi să facă tot ce îi stă în putinţă să îşi îndeplinească atribuțiile de serviciu bazându-se pe onoare şi respect. Datorită acestui fapt, a fi polițist nu e doar o carieră ce poate fi urmată, ci un stil de viaţă. Inclusiv prietenii pe care polițistul îi are trebuie să fie selectaţi cu mare grijă, aceştia nu ar trebui să se numere printre suspecții unor cauze ce se află pe rolul instanțelor, dar nici care să încalce pur şi simplu legea. Odată ce un polițist este văzut în compania unei interlop, de exemplu, cetățenii nu se vor mai axa pe acțiunile acestora, ci pe faptul că are relații cu o persoană care nu se ridică la standardele acestuia şi sfidează instituția pe care o reprezintă.

\section{Imaginea publică a Poliţiei Române}

Imaginea publică a Poliției Române este percepută de fiecare persoană diferit, deoarece orice cetățean are dreptul la părerea proprie. Odată cu democratizarea României a început să crească încet, încet încrederea cetățeanului în organele de poliție. Astfel, imaginea de ansamblu a instituției a început să fie una mai bună, fiind în continuă dezvoltare.

Există mai mulți factori care influențează percepțiia societăţii asupra Poliției Române. De-a lungul timpului au existat mai multe cercetări care au avut ca scop descoperirea unor elemente care ar putea înclina balanţa într-un mod negativ sau pozitiv.

Minorităţile, de obicei, nu sunt relevante în constituirea unei imagini publice a unei instituții de stat. De cele mai multe ori, minoritățile etnice nu au puterea necesară de a constitui un factor ce ar putea influența cetățenii cu privire la părerea lor despre o anumită instituție sau despre un anumit subiect. In urma unor studii s-a observat faptul că această categorie socială are un impact asupra societății în care trăiesc, mai mult, nu unul pozitiv. Minoritățile afectează încrederea unei persoane în poliție, deoarece acestea adeseori au probleme cu legea sau consideră că nu sunt îndreptăţite şi că nu le sunt întotdeauna respectate drepturile. Desigur, nu obligă pe nimeni să aibă aceeaşi părere pe care o împărtăşesc, dar pot aduce anumite exemple prin care să demonstreze că au dreptate referitor la argumentele pe care le fac (Moris, 2011, p. 79). 
Satisfacția referitoare la modul de trai împreună cu încrederea politică s-au dovedit recent a fi nişte elemente care pot prezice modificarea nivelului de încredere în poliție. Încrederea politică pe care o are o persoană este în strânsă legătură cu cea pe care pe care o au în organele de poliție. De asemenea, satisfacția şi nivelul de trai afectează uşor modul în care este percepută poliția de către cetățeni.

Vârsta este un alt aspect care se află în strânsă legătură cu nivelul de încredere pe care îl are societatea în poliție. Persoanele care au o vârstă mai innaintată au un mai mare respect pentru organele de poliție, considerându-se mai în siguranţă în preajma acestora.

Statul democratic reprezintă un alt aspect care îi ,ajută” pe cetățeni să îşi formeze o opinie despre instituțiile din cadrul acestuia. În cazul în care regimul este unul totalitar, poliția s-ar putea să lucreze doar pentru stat şi în interesele acestuia, nu şi în interesul populației. Din acest motiv, democraţia joacă un rol important în crearea nivelului de încredere pe care îl au cetățenii în Poliția Română.

Imaginea Poliției Române este atent analizată de către societate, avându-i în vizor pe poliţişti, cercetându-le acestora fiecare pas pe care îl fac. De cele mai multe ori, comportamentul nu tocmai exemplar al unui polițist va fi criticat de către cetățeni şi se va generaliza, considerându-se că oricare altă persoană din structură ar putea face acelaşi lucru. De asemenea, activitătile pe care Poliția Română le desfăşoară cu scopul prevenirii şi combaterii criminalității în serie ajută la definirea unei imagini care nu poate fi denigrată (Rotaru, 2013).

\section{Scopul şi obiectivul lucrării}

În zilele noastre, rata criminalităţii nu a încetat să scadă, iar din acest motiv este nevoie, în special, de ajutorul Poliției Române. Personalul care face parte din această structură din cadrul Ministerului Afacerilor Interne se ocupă atât de soluționarea sezisărilor pe care le primesc de la cetățeni, cât şi de prevenirea săvârşirilor infracțiunilor prevăzute de legea penală prin diferite metode şi programe.

Pentru ca Poliția Română să reuşească să-şi îndeplinească atribuțiile, aceasta are nevoie ca cetățenii să aibă încredere în munca pe care o depune. Datorită opiniilor diferite care au luat naştere de-a lungul timpului, o analiză a încrederii pe care o au cetățenii în această instituție este una bine-venită.

Această lucrare îşi propune să descopere nivelul de încredere pe care cetățenii îl au în Poliția Română. Fiind un aspect care cântăreşte mult în ceea 
ce priveşte imaginea publică şi sfera vieții sociale, această cercetare este una de actualitate, iar analizarea rezultatelor ar putea duce la o mai bună comunicare şi la întărirea relației dintre cetățeni şi Poliţia Română (2014).

Odată ce nu mai există încredere într-o instituție sau nivelul acesteia scade dramatic, eficacitatea va scădea şi ea. Atribuțiile de serviciu nu vor mai fi îndeplinite în interesul cetățeanului, sau chiar dacă ar fi îndeplinite, s-ar putea să nu îl afecteze pe acesta în vreun fel, pozitiv sau negativ.

Obiectivul urmărit de această cercetare este măsurarea încrederii cetățenilor în personalul din Poliția Română, respectiv respectul pe care aceştia îl au şi, totodată, elementele care ar putea influenţa pozitiv sau negativ acest aspect. Pentru a se putea îndeplini acest obiectiv, au fost realizate anumite activităţi:

- Identificarea unor instrumente valide prin intermediul cărora este posibilă evaluarea încrederii pe care o au cetățenii în Poliția Română;

- Elaborarea unui chestionar pe baza căruia este posibilă identificarea încrederii pe care o acordă cetățenii personalului din Poliția Română;

- Realizarea unei baze de date şi analiza statistică a datelor obținute.

Această cercetare şi-a propus abordarea nivelului de încredere acordat Poliției Române ca pe un proces de construcție. S-a făcut o paralelă între familia pe care au avut-o subiecții când au fost minori şi familia pe care aceştia o au în prezent. Pe lângă acest aspect, lucrarea şi-a propus să stabilească dacă subiecții au avut antecedente penale, acest element fiind considerat unul care ar putea influența într-o măsură importantă răspunsul persoanelor anchetate. Mai mult, s-a încercat identificarea unor factori care ar putea înclina balanța într-o altă direcție în ceea ce privește perspectiva subiecților.

\section{Ipotezele cercetării}

Această cercetare are la bază trei premise:

- Familia din care cetățenii fac parte influențează încrederea pe care aceştia o au în Poliția Română.

- Principalul factor care influențează nivelul de încredere acordat Poliției Române este corupția.

- Comportamentul şi pregătirea polițiştilor au un rol important în creşterea sau scăderea încrederii.

Ipotezele de lucru (operaţionale) care ne-au orientat în analiza cantitativă a răspunsurilor participanților au fost: 
- Cetățenii care provin din familii dezorganizate au o încredere scăzută în Poliţia Română.

- Datorită nepăstrării secretului profesional de către unii polițişsti, încrederea cetățenilor a scăzut.

\section{Descrierea eşantionului}

Cercetarea despre nivelul de încredere în Poliția Română a avut ca grup țintă cetățenii din Municipiul Suceava, de vârste diferită şi care provin din familii/medii diferite, acest fapt asigurând un eşantion reprezentativ prin diversitate.

La baza eşantionului stă metoda bulgărelui de zăpadă. Subiecții care au participat la această cercetare au fost împărțiţi atât în funcție de sex, cât şi în funcție de vârsta pe care o au la momentul răspunderii chestionarului, şi anume: între 18 şi 30 de ani, între 30 şi 50, ultima categorie fiind între 50 şi 70. Această metodă s-a dovedit a fi una eficientă deoarece datorită diferențelor dintre subiecți, răspunsurile pe care acestea le-au dat au dus la rezultate complexe.

Chestionarul a fost aplicat unui număr de 100 de subiecți, acest fapt ducând la un eşantion de mare dimensiune, având în vedere că au participat peste 30 de indivizi. Mai mult, unul din cinci subiecți care treceau prin faţa Universității din Municipiul Suceava era abordat pentru a completa chestionarul.

\section{Preancheta}

Preancheta a fost realizată cu scopul de a modifica întrebările cuprinse în chestionar în aşa fel încât rezultatele să fie cât mai concrete şi mai concise. Datorită acestui lucru, s-a realizat un chestionar care s-a aplicat unui număr de 10 subiecți, răspunsurile şi părerile acestora fiind elemente esențiale în modelarea chestionarului final.

Inițial, a doua întrebare din componența instrumentului folosit se referea la vârsta subiectului şi cuprindea mai multe variante din care acesta putea să aleagă doar una singură, şi anume: a) 14-18 ani, 18-20 de ani, 20-30 de ani, 30-50 de ani şi 50-70 de ani. In urma preanchetei s-a observat faptul că existau prea multe categorii de vârstă, iar acest lucru ducea la un rezultat cu o pondere semnificativ de mică. De asemenea, categoria 14-18 ani a fost exclusă deoarece adolescenții care nu au împlinit vârsta de 18 ani s-ar putea să nu fie la fel de interesați de modul în care membrii din structura Poliției Române îşi îndeplinesc atribuțiile de serviciu sau de încrederea pe care o au 
aceştia în această instituţie. Mai mult, s-a considerat că răspunsul persoanelor care s-ar fi încadrat în această categorie nu ar fi condus la un rezultat concret şi care să reflecte realitatea la o scară mai largă.

Întrebarea cu numărul 8 avea ca scop clasificarea subiecților în funcție de nevoia lor de Poliția Română, mai exact, dacă au apelat aceştia „recent” la serviciile acestei instituții. Răspunsurile a) da şi b) nu, s-au dovedit a nu fi suficiente, ceea ce a dus la restructurarea întrebării. Aceasta apare în chestionarul final sub forma a două întrebări, considerându-se mai important dacă subiecții au apelat anul acesta, anul trecut etc. la serviciile Poliției Române, decât dacă au apelat sau nu, în general.

Intrebarea 13 era una deschisă, în sensul că dădea dreptul subiectului să vină cu propria părere. În urma preanchetei s-a ajuns la părerea că cel mai eficient ar fi prezentarea a cinci factori care ar putea influența nivelul de încredere. Astfel s-ar putea determina un procent pentru fiecare factor, observându-se dacă afectează într-un fel sau nu încrederea.

De asemenea, această preanchetă a ajutat şi la diversificarea eşantionului. În timpul preanchetei, chestionarul a fost aplicat fiecărei persoane care a trecut printr-o zonă, astfel neasigurându-se o cercetare aleatorie.

\section{Instrumentele utilizate pentru cercetarea datelor}

Ancheta realizată cu ajutorul chestionarului este una dintre cele mai cunoscute şi utilizate metode de cercetare la nivel social (Sandu, 2014). In ceea ce priveşte definirea acesteia, literatura de specialitate a încercat în numeroase rânduri să o definească.

„Ancheta reprezintă o metodă de interogare asupra faptelor sociale (opinii, atitudini, motivații etc.) la nivelul grupurilor umane, mai mici sau mai mari, de analiză cuantificabilă a datelor, în vederea descrierii şi explicării lor. Din perspectiva lui Roger Mucchielli, chestionarul constă doar într-o enumerare de întrebări”" (Sandu, 2014).

Chestionarul care a stat la baza acestei cercetări sociologice a fost constituit din 20 de întrebări. Primele patru întrebări au ca scop identificarea subiectului şi încadrarea acestuia într-o categorie (în funcţie de sex, vârstă, familie).

De la întrebarea 5 la întrebarea 8 , prin răspunsurile oferite se încearcă o catalogare a subiectului, deoarece aceste aspecte cheie pot influența într-o mare măsură răspunsurile care urmează. Referitor la întrebarea 5, în general, persoanele care au un membru din familie în structura Poliției Române, 
acestea tind să aibă mai multă încredere în această instituție, deoarece au mai multe informații din „interior”, ştiu prin ce trec şi ce atribuţii trebuie să îndeplinească.

De asemenea, acestea înțeleg şi riscul pe care şi-l asumă fiecare polițist în momentul în care îmbracă uniforma şi este în timpul serviciului. Celelalte persoane, care văd lucrurile din exterior, nu ştiu exact ceea ce se întâmplă cu adevărat sau ce riscuri îşi asumă fiecare persoană din cadrul instituției Poliției Române atunci când se află la muncă.

În ceea ce priveşte întrebările cu numărul 6 şi 7 , cei a căror membru din familie a avut antecedente penale, sau care ei înşişi au fost anchetaţi, tind să nu aibă un nivel ridicat de încredere în Poliția Română. În majoritatea cazurilor aceştia consideră că au fost neîndreptățtiti sau chiar acuzați şi pedepsiți pe nedrept.

Deoarece există mulți factori care influențează nivelul încrederii pe care îl au cetățenii în Poliția Română, cu ajutorul următoarelor întrebări s-a încercat o identificare a acestora.

Pentru a afla cu certitudine dacă aceste situații sunt adevărate, se vor analiza datele strânse în urma completării chestionarelor de către subiecți.

Cercetarea a fost realizată $\mathrm{cu}$ ajutorul chestionarului pentru determinarea încrederii cetățenilor în Poliția Română în anul 2017, în perioada 15-20 august. Strângerea datelor a fost efectuată de către studenta Paşniciuc Larisa-Ionela, autorul lucrării prezente.

\section{Rezultatele obţinute şi interpretarea lor}

Strângerea datelor a reprezentat o etapă importantă în realizarea acestei anchete. Rezultatele obținute în urma completării chestionarelor de către subiecți au fost prelucrate manual, iar interpretarea acestora s-a bazat strict pe informațiile obținute.

Prima întrebare a chestionarului urmăreşte identificarea subiecților având la bază sexul acestora. În urma contorizării rezultatelor s-a obținut o majoritate constituită din subiecți de sex feminin, şi anume $55 \%$. In ceea ce priveşte reprezentanţii sexului masculin, s-a înregistrat un procent de $45 \%$ dintre subiecții care au răspuns la acest chestionar. 


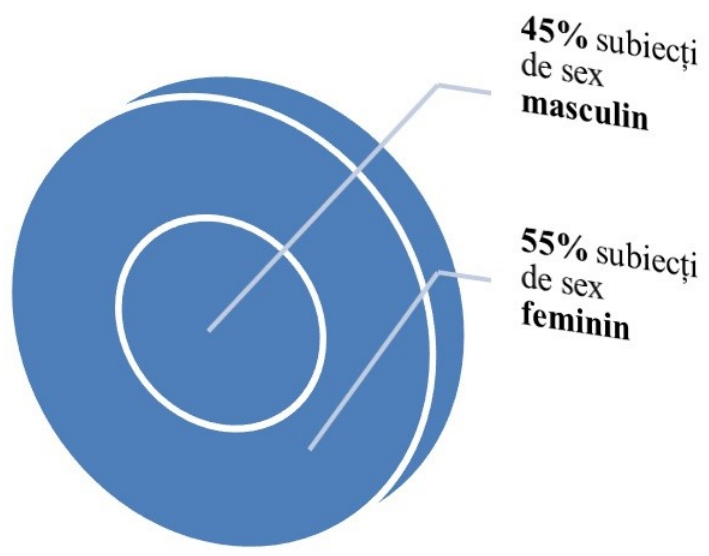

Întrebarea cu numărul 1 nu a fost adresată doar pentru a face o diferență între subiecți, ci pentru a afla dacă încrederea în poliția Română poate varia sau este influențată de sexul subiectului.

Intrebarea cu numărul doi şi-a propus o clasificare a persoanelor care au răspuns acestui chestionar în funcție de vârstă. Pragul minim a fost de 18 ani, deoarece s-a considerat că până la acea vârstă este posibil ca o mare parte dintre potențialii subiecți să nu fi interacționat niciodată cu Poliția Română sau să nu ştie care îi sunt atribuțiile acesteia.

Datorită acestor circumstanțe, s-a considerat că ar putea fi duse în eroare rezultatele obţinute, acestea nefiind concrete şi cât se poate de concise. Mai mult, având în vedere că 18 reprezintă vârsta majoratului în România, iar abia după împlinirea acesteia i se cuvin anumite drepturi, multe persoane nu ar fi fost în cunoştinţă de cauză.

Având în vedere că nu a fost un folosit un număr mare de subiecți, fiecare răspuns în parte poate afecta într-un mod negativ sau pozitiv rezultatele finale.

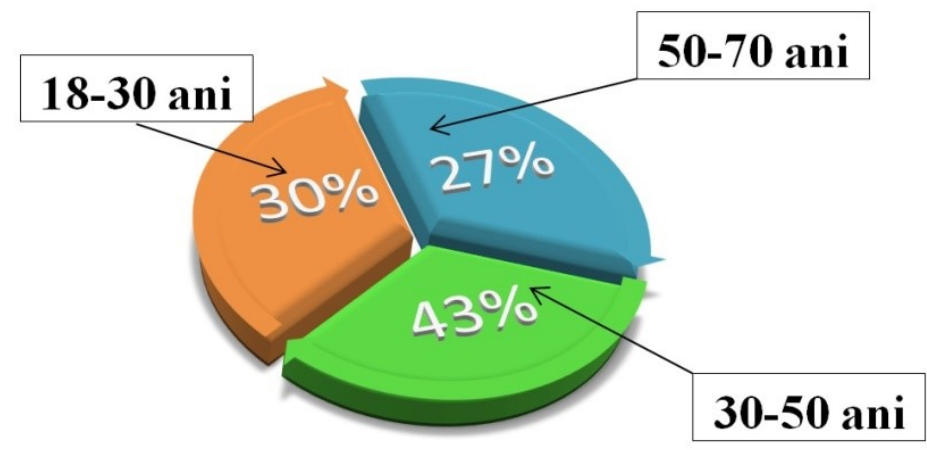


S-au considerat a fi oportune trei categorii de vârste: $18-30$ ani, 30-50 ani şi 50-70 ani. Rezultatele au arătat că subiecții: 30\% au avut vârsta între 18 şi 30 de ani, 43\% s-au încadrat în categoria de vârstă 30-50, iar 27\% au avut vârsta cuprinsă între 50 şi 70 de ani. După cum se observă, predomină persoanele din clasa mijlocie, fiind urmate de cele mai tinere, iar pe ultimul loc se află cei în vârstă.

Răspunsurile întrebărilor 3 şi 7 au fost analizate în paralel pentru a putea avea un rezultat final concludent. În urma studierii alegerilor făcute de către subiecți, s-a ajuns la concluzia că doar $6 \%$ dintre aceştia au răspuns pozitiv la întrebarea numărul 7.

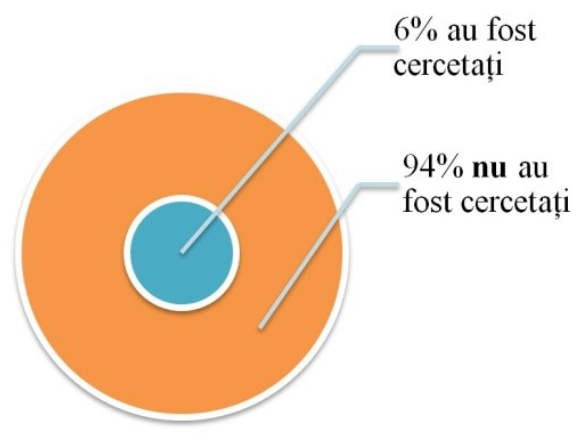

S-a considerat a fi important mediul din care provin subiecții, presupunându-se că există o legătură între mediul în care au trăit şi modul în care s-au dezvoltat în viaţă. Mai întâi de toate a fost necesară stabilirea sexului subiecților care au săvârşit fapte penale. Din procentul de $6 \%, 33,3 \%$ au fost de sex feminin şi $66,7 \%$ de sex masculin.

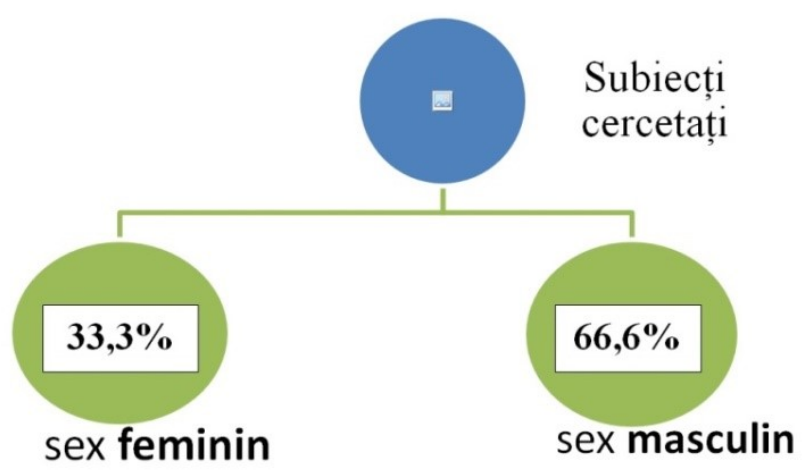

Un astfel de rezultat era de aşteptat, deoarece s-a plecat de la premisa că persoanele de sex masculin comit mai multe infracțiuni decât cele de sex feminin. Bărbaţii sunt predispuşi la încălcarea mai deasă a legii, deoarece aceştia, de obicei, acționează mai mult pe moment şi din cauza impulsurilor, 
destul de rar premeditând ceea ce urmează să facă. În ceea ce priveşte femeile, acestea de cele mai multe ori îşi calculează foarte atent mişcările pe care le fac. Încearcă să îşi acopere urmele şi datorită faptului că nu sunt neglijente, organele de poliție le identifică foarte greu.

Intrebarea cu numărul 4 a avut ca scop determinarea mediului în care s-au dezvoltat subiecții. Persoanele de sex feminin care au fost cercetate pentru săvârşirea unor infracțiuni au provenit dintr-o familie în care cel puțin unul dintre părinți a decedat.

In urma analizării rezultatelor, subiecții de sex masculin care au comis o faptă penală au avut părinții divorțaţi. $\mathrm{O}$ concluzie rapidă poate fi aceea că, într-un fel sau altul, situația familială în care este crescută o persoană poate afecta conduita acesteia în anii următori.

Se poate considera că părinții reprezintă stâlpul familiei, iar atunci când cel puțin unul dintre ei încetează din viață, modul în care gândeşte şi se comportă copilul rămas orfan este afectat. Asta nu înseamnă că persoanele care provin dintr-o familie unită nu pot comite infracțiuni, ci că riscul nu este la fel de mare ca în celălalt caz.

S-a plecat de la premisa că persoanele care au în familie cel puțin un membru care lucrează în cadrul Poliției Române, cunosc mai bine modul în care aceştia din urmă îşi desfăşoară activitatea. Astfel, întrebarea numărul 5 încearcă să afle dacă au exemple în familie care lucrează în Poliție, iar răspunsul acesteia va fi corelat cu cel al întrebării cu numărul 12.

Dintre cei 100 de subiecți, doar 14\% dintre aceştia au în familie o persoană care lucrează în cadrul Poliției Române, iar restul de $86 \%$ nu se încadrează în această categorie.

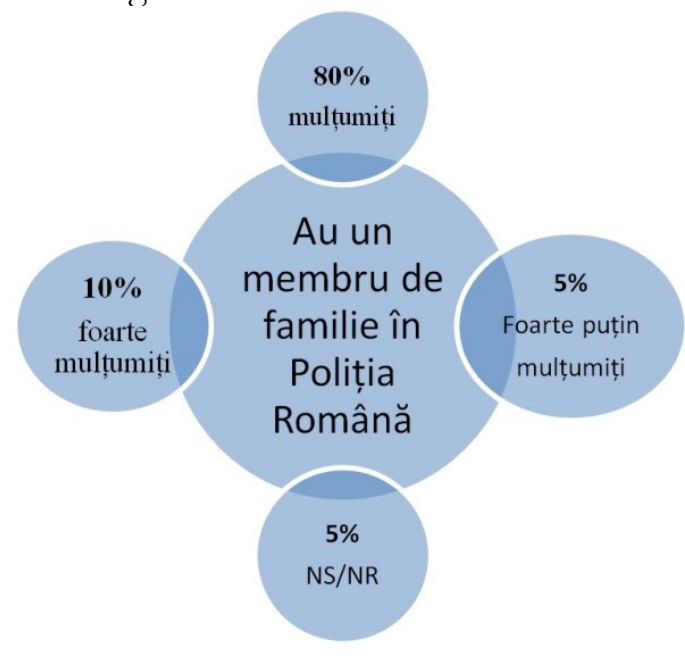

60

How to cite: Pasniciuc, L.I. (2017). Citizens' Trust in the Romanian Police. Logos Universality Mentality Education Novelty, Section: Law, V(2), 48-66. https://doi.org/10.18662/lumenlaw.4 
Având în vedere procentul de 14\%, s-a încercat identificarea măsurii în care Poliția Română îşi îndeplineşte datoria faţă de cetățeni. S-a avut în calcul doar acest procentaj, deoarece s-a dorit verificarea premisei potrivit căreia cei care au un membru de familie în cadrul acestei instituții cunosc mai bine situația în care se află aceştia.

În acest caz, majoritatea - 80\% dintre cei care au un membru de familie în Poliție - au considerat că sunt mulțumiţi de modul în care Poliția Română îşi face datoria față de cetățeni. Un procent de 10\% s-a declarat a fi foarte mulțumit de activitatea acestei structuri raportate la cetățeni, iar 5\% consideră că sunt foarte nemulţumiţi şi $5 \%$ nu au dorit să răspundă la această întrebare, sau nu ştiu.

În general, ori de câte ori într-o zonă se află un polițist, cetățenii se simt în siguranță, deoarece aceştia cred că astfel nu îi va ataca nimeni sau şansele ca acest fapt să se întâmple sunt foarte mici. Cei 100 de subiecți au fost rugaţi să răspundă la întrebarea numărul 13 pentru a se putea observa dacă cetățenii se consideră a fi în siguranță atunci când observă prezența unui angajat din cadrul Poliției în locul în care se află.

Rolul polițiştilor este de asigurarea şi respectarea drepturilor cetățenilor, dar şi de a menține ordinea şi liniştea publică. Aceste atribuții implică şi asigurarea unui mediu în care cetăţeanul poate să işsi trăiască viaţa fără a fi stingherit. Lucrul acesta este posibil doar în măsura în care polițiştii mențin siguranța publică.

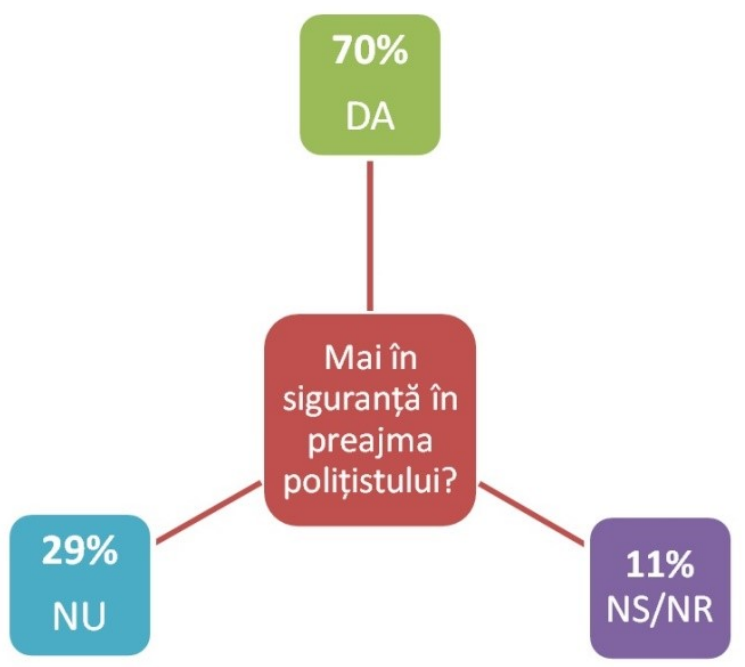

Un procentaj de $70 \%$ consideră că există o diferenţă dacă simt prezența polițistului în zona prin care trec. $29 \%$ dintre subiecți au fost de 
părere că nu simt vreo diferență în momentul în care există sau nu un organ de poliție, iar $11 \%$ au preferat să răspundă folosind varianta nu ştiu/nu răspund. Astfel, se poate observa din analiza răspunsurilor acordate acestei întrebări faptul că societatea încă are încredere în Poliția Română, simţinduse în siguranţă atunci când prin preajma cetățenilor se află un polițist.

Atunci când vine vorba de un polițist, există sau nu anumiţi factori care i-ar putea influența modul în care îşi îndeplineşte atribuțiile de serviciu? Prin întrebarea numărul $14 \mathrm{~s}-\mathrm{a}$ urmărit identificarea unor aspecte care ar putea avea un efect asupra încrederii pe care o are societatea în Poliția Română.

În urma analizării rezultatelor, a reieşit faptul că subiecții chestionați au fost de părere în proporție de $37 \%$ că un factor care influențează încrederea pe care o au cetățenii în Poliție este corupția.

Următorul loc îl ocupă personalul insuficient cu 17\%, altele $(13 \%)$, bugetul insuficient (12\%), nu ştiu/nu răspund $(9 \%)$, niciunul $(5 \%)$, pe ultimul loc clasându-se transparența $(5 \%)$. Corupția este un subiect sensibil la nivel de țară, iar tot ceea ce se întâmplă la nivel național afectează într-un fel sau altul încrederea cetățenilor.

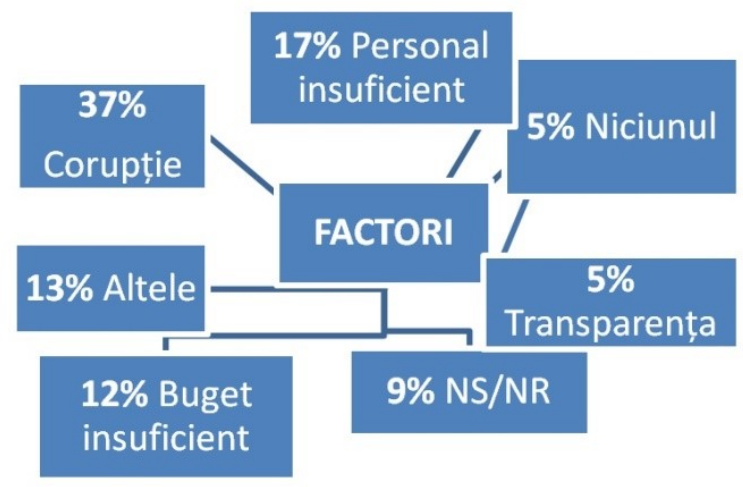

Conduita polițistului trebuie să fie una impecabilă, iar acesta nu are dreptul să se afilieze cu anumite grupări care încalcă legea. De asemenea, potrivit regulilor şi legilor care guvernează desfăşurarea acţiunilor poliţistului, acestuia îi este interzis să pretindă sau să primească bani sau alte foloase pentru a-şi îndeplini într-un anumit mod atribuțiile pe care le are.

Mai mult, dacă un polițist este privit de către cetățeni ca fiind corupt, aceştia nu vor avea încredere în el şi vor fi de părere că există mai mulţi ca el. Acest lucru duce cu gândul la îndeplinirea defectuoasă a atribuțiilor, 
oferindu-le unor anumite persoane unele portițe pentru a scăpa de urmările ce se nasc în momentul comiterii unei infracțiuni.

Un alt aspect important din cadrul activității profesionale ale polițistului este păstrarea secretului profesional. Cei 100 de subiecți au fost rugați să răspundă la întrebarea cu numărul 15 pentru a se putea crea o imagine asupra părerii pe care o au referitoare la păstrarea secretului profesional de către polițist.

Răspunsul a fost unul destul de strâns din perspectiva procentajului, 35\% din persoane au considerat că polițiştii păstrează într-o măsură mare secretul, iar 37\% au fost de părere că aceştia îndeplinesc doar într-o măsură mică această atribuție de serviciu. 13\% au considerat că secretul nu este tratat aşa cum ar trebui de către organele de poliție, fiind de părere că nu este păstrat deloc, iar 15\% au refuzat să răspundă, alegând varianta nu ştiu/nu răspund.

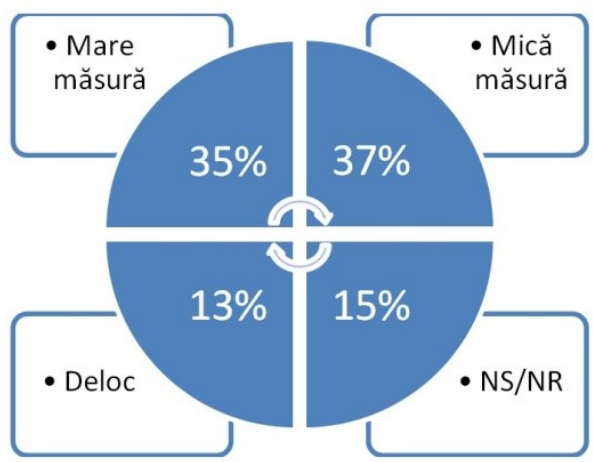

Acest rezultat este unul îngrijorător deoarece acțiunile polițistului au la bază confidențialitatea şi respectul faţă de profesia pe care o deţine şi instituția pe care o reprezintă. Dacă din perspectiva cetățenilor polițiştii nu reuşesc să păstreze secretul profesional, atunci aceştia nu vor avea încredere şi nu vor colabora cu organele de poliție. Chiar dacă vor dori să facă un denunt, probabil vor gândi de două ori înainte de a face pasul, neştiind dacă suspectul va afla între timp cine a fost denunțătorul pentru a se putea răzbuna. Deoarece Poliția se asigură de respectarea şi aplicarea legii, cum ar mai putea un cetățean să aibă încredere în această instituție dacă persoanele care o reprezintă încalcă atribuțiile pe care le au?! Încrederea este câştigată prin comportamentul exemplar pe care îl adoptă un polițist în timpul serviciului şi modul în care îşi îndeplineşte toate atribuțiile în legătură cu profesia. 
Pe lângă secretul profesional, se pune accentul şi pe modul în care îşi exercită polițistul puterea cu care a fost investit. Întrebarea 20 surprinde un aspect delicat, acela făcând referire la faptul că polițistul foloseşte autoritatea pe care au dobândit-o şi în interes personal, nu numai în interes public. Rezultatul a fost din nou unul destul de apropiat, dar majoritatea a fost de părere că polițistul foloseşte autoritatea doar în interesul serviciului, procentul fiind de $45 \%$. Foarte aproape se află şi subiecții care au fost de părere că nu este tocmai adevărat acest lucru - 33\%. De asemenea, 19\% dintre cei care au completat chestionarul au ales a treia variantă, nu ştiu/nu răspund. Acest rezultat implică faptul că majoritatea oamenilor consideră că polițiştii nu îşi folosesc autoritatea cu care au fost investiți în scop personal, ceea ce înseamnă că încrederea în instituție încă mai există.

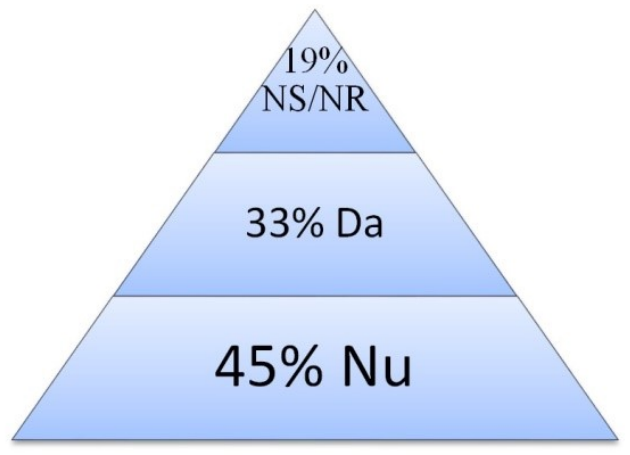

Intrebarea cu numărul 9 a fost folosită în chestionar pentru a se încerca desprinderea unei imagini pe care o au cetăţenii asupra Poliției Române. 33\% dintre răspunsuri au fost constituite din cuvântul „siguranţă”, iar imediat după, cu un procent de 19\% s-a situat cuvântul „ordine”. Desigur, au mai fost utilizate şi alte cuvinte de către subiecți precum „ajutor”, (8\%), „protecție” (5\%) „lege” (4\%), „apărare” (2\%), „respect” (1\%), „impunere” (1\%), şi „dreptate” (1\%). Cu toate acestea, un procent de $26 \%$ dintre subiecți au refuzat să răspundă la această întrebare.

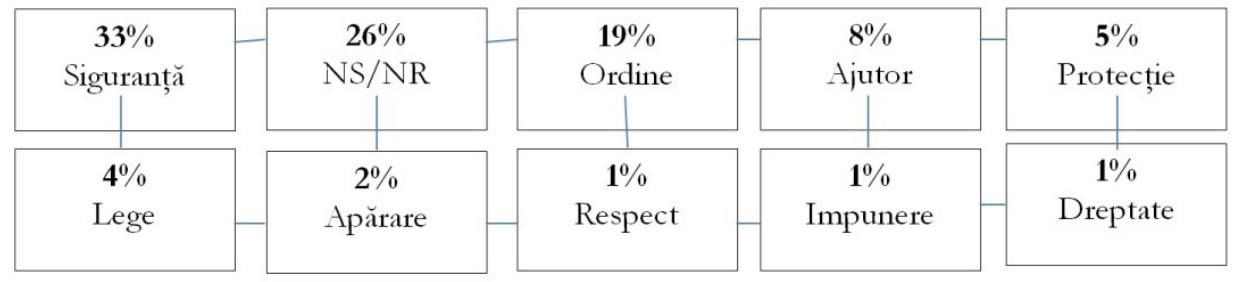


Având în vedere răspunsurile oferite de către subiecți, se poate considera faptul că aceştia încă mai au încredere în Poliţia Română şi în personalul din subordinea acestuia. De asemenea, venindu-le pentru prima dată în minte cetățenilor cuvântul ,siguranță”, acest fapt înseamnă că polițiştii îşi îndeplinesc conform legii atribuțiile.

În urma analizei răspunsurilor oferite de către subiecți, cetățenii încă mai au încredere în organele de poliție, chiar şi dacă au mai existat incidente mai mici sau mai mari la nivelul statului.

\section{Concluzii}

Rezultatele obținute au arătat că premisele de la care a început această anchetă sunt adevărate doar într-o anumită măsură. Prima premisă a fost aceea potrivit căreia familia din care cetățenii fac parte influențează încrederea pe care aceştia o au în Poliția Română. Potrivit rezultatelor obținute prin completarea chestionarelor de către subiecți a reieşit faptul că familia poate influența nivelul încrederii, dar nu se poate obține un procent general.

De obicei, cei care provin dintr-o familie organizată a căror părinți au fost în viaţă în timpul copilăriei, nu au fost cercetați penal, nesăvârşind infracțiuni. Cei care au provenit din familii cu un singur părinte au fost predispuşi la comiterea unor fapte ilegale, iar mai apoi, după ce au intrat în contact cu organele de poliție, încrederea acestora a început să scadă. Cel mai intâlnit motiv este acela potrivit căruia făptuitorii care fac parte din astfel de familii consideră că sunt neîndreptățiți, şi prin aplicarea legii nu se face nimic altceva decât nedreptate.

A doua premisă care stă la baza cercetării se referă la principalul factor care poate influența încrederea acordată Poliției Române de către cetățeni. S-a pornit de la ideea că cel mai important factor este corupția. In urma analizelor datelor s-a constatat că această premisă este una valabilă. Majoritatea subiecților au considerat că acesta ar fi unul dintre motivele principale pentru care populația începe să îşi piardă încrederea în organele de poliție. Acest factor nu este izolat şi nu este întâlnit doar în cadrul Poliției Române şi nu face referire doar la această instituție.

Odată ce corupţia apare la nivelul statului, este inevitabilă răspândirea acestuia şi la instituțiile cu care acesta are legături. Acest fapt nu demonstrează că astfel de acțiuni chiar au loc, dar cetățenii asociază statul şi autoritatea cu poliția, iar de aici se nasc bănuielile. De asemenea, dacă un 
polițist este surprins săvârşind infracțiunea de luare sau dare de mită, nu doar acesta va avea de suferit, ci întreaga instituție pe care o reprezintă.

Comportamentul şi pregătirea polițiştilor sunt doi factori care au un rol important în creşterea sau scăderea încrederii în Poliţia Română. Odată ce un polițist nu este civilizat şi abordează un comportament ce nu se încadrează normelor morale şi general valabile, acesta nu va mai putea fi un exemplu pentru societate.

Imaginea Poliției Române este influențată de mai mulţi factori, iar cetățenii trebuie să ia în calcul nu doar greşelile făcute de către personalul care lucrează în această instituție, ci şi de rezultatele obţinute în urma misiunilor realizate de către aceştia.

Odată ce încrederea este pierdută, societatea nu va mai putea evolua, democrația, în cel mai bun caz, va stagna, dacă nu va şi dispărea.

Un stat democratic nu poate exista fără ajutorul Poliției. Dacă cetățenii nu cooperează cu această instituție şi nu apelează cu încredere la serviciile acesteia, organizațiile criminale vor continua să se dezvolte, iar siguranța cetățeanului va fi pusă în pericol.

\section{References}

INSCOP Research (2015a). Încrederea în institutii. Retrieved from http://www.inscop.ro/septembrie-2015-increderea-in-institutii/

INSCOP Research (2015b). Increderea in institutii. Retrieved from http://www.inscop.ro/decembrie-2015-incredere-institutii/

INSCOP Research (2016). Increderea in institutii. Retrieved from http://www.inscop.ro/aprilie-2016-increderea-in-institutii/

Moris, C. (2011). A Cross-National Study on Public Confidence in Police. Boston (Massachusetts): Northeastern University.

Poliția Română (2014). Scurt istoric. Retrieved from https://www.politiaromana.ro/ro/informatii-generale/scurt-istoric

Rotaru, C. (2013). Unele aspecte privitoare la activitatea de prevenire a criminalității. Studii de securitate publică, Vol. II, Nr. 1(5), 10. Retrieved from http://ssp.academiadepolitie.ro/revista/rev5.pdf

Sandu, A. (2014). Seminarii de etică şi sociologie. Iaşi, România: Editura Lumen. Ştefan, C-E. (2013). The Police Life in The Society. Studii de securitate publică, Vol. II, Nr. 3(7). Retrieved from http://ssp.academiadepolitie.ro/revista/rev7.pdf 